\title{
INTERACTION PATTERN BETWEEN FISHERS AND FOREIGN INVESTORS IN THE FISHING BUSINESS AND ITS IMPLICATIONS (A CASE IN NUNUKAN REGENCY, EAST KALIMANTAN)
}

\author{
lin Solihin"), Sugeng Hari Wisudo2), John Haluan"3), and Drajat Martianto() \\ 1) Graduate Student in Marine Technology, Graduate School, Bogor Agricultural University \\ 2) Lecturer in Fisheries Resource Utilization Department, Bogor Agricultural University \\ 3) Lecturer in Fisheries Resource Utilization Department, Bogor Agricultural University \\ 4) Lecturer in Community Nutrition Department, Bogor Agricultural University \\ Received November 30-2009; Received in revised form November 8-2011; Accepted November 11-2011 \\ e-mail: insol_ipb@yahoo.com,iin_solihin@ipb.ac.id; blog : iin_solihin.staff.ipb.ac.id
}

\begin{abstract}
The objective of this research is to determine patterns of interaction between fishers and foreign investors (Malaysia) in the fishing business. Research conducted on May 2009 in the Nunukan, East Kalimantan. The data retrieval was conducted by in depth interviews (deep interviews) with the fishers and middlemen as well as direct observations on the condition of the fishing business and marketing in both the Nunukan District and in Tawau Malaysia. The results showed that there is a relatively large dependence of the fishers in Nunukan District to the owners of capital from Tawau regarding capital provision, marketing of the catch, and social security.
\end{abstract}

\section{KEYWORDS: Fishers, foreign investors, border area, Nunukan Regency}

\section{INTRODUCTION}

According to the Presidential Regulation of the Republic of Indonesia Number 78 Year 2005 concerning the management of outer small islands, there are 92 outer islands. The potential of natural resources owned by the majority of Indonesia's outer region is marine and fishery resources. This is understandable since Indonesia is an archipelago in which aspects of marine resources became very dominant. Fisheries and marine sectors considered the basis and the mainstay of economic development of these border regions.

In fact the border areas with the marine and fisheries resources basehave not been developed. Limited access to and from these areas causes economic activity and development in the region has not been optimally implemented. On the other hand, the access area to neighboring countries is relatively better by which makes the interaction between Indonesian communities in the outer regions and neighboring communities more intensive than other communities in the territory of Indonesia.

One of important aspect for accesses in the developing fisheries business is the access to capital. It is well known that fishers had limitation to capital access so that to solve it, they had to owe it to the owners of capital. This has implications for the dependence of fishers to the owners of capital. The problem became so important when the owners of capital were from other countries. Besides the personal attachment of fishers, it is also strongly associated with resource utilization patterns of fish in Indonesian waters, food security in term of protein sufficiency from fish, and economic growth of border regions as a whole.

Such a case also occurred in the area of Nunukan Regency which borders with Malaysia. The purpose of this research is, to understand the relationship between fishers and foreign investors in the fishing business.

\section{MATERIALS AND METHODS}

Research conducted in May 2009 took place where the fishers were concentrated in Nunukan Regency that is, in the Nunukan and Sebatik Island. Method used for data acquisition was in depth interviews with the fishers and middlemen and also observations. Respondents were taken to represent fishing equipments used and their houses. The method of sampling was purposive sampling where respondents understand about fishing and marketing fact in the study location. The things asked to them were business scales, investment, and operational costs required, the source of capital and repayment patterns, the number and type of catch yield per trip, the selling price of the catch and marketing purposes. The numbers of respondents are 15 people. Data were 
analyzed descriptively by linking the various facts collected either through interviews or observations. Although Nunukan fishers could sell their catch to other regions in Indonesia, for example Tarakan, Balikpapan etc., they did not do it. They prefer to sell these catch to Tawau Malaysia. Therefore, this research analyzed fishing business performance and foreign investor role relationship, especially in fishing capital supply and catch marketing.

\section{RESULTS AND DISCUSSIONS}

\section{Results}

Fishers in the Nunukan District were still operating traditional fishing in the surrounding of Nunukan waters. Travel time required to reach the fishing areas ranged between half an hours to an hour. Fishing areas in Nunukan District can be divided into several zones according to the fishing equipments used by local fishers. Sebuku River Estuary area to the south of Nunukan Island; namely, between Cantik Cape and Pukat Islands was the bag net operating area (trawling or dogol) drawn by a motor boat under $5 \mathrm{GT}$, while the operation area with fishing poles were found in almost all waters of Nunukan District. Along the coast from Sebatik Island to Arus Cape was the operating area of klitiknet (longish nets) and gill nets. Fishing ground of Dara shellfish was around the Cantik Cape, on the east coast of Nunukan Island and south Tinabasan Island, while there was oyster fishing ground around Tinabasan Island. Regional operations of fishing equipment of tanang (hampang) and fishing platforms/ jermal (kelong) were all around the east coast of Nunukan Island. While in the north of Bukat Island and the south coast of Nunukan was an area of operations using fishing equipment of julu (tugu).

Based on geographical distribution, fishers of Nunukan Regency spread along the coast of Sebatik Island including Liang Bunyu, Bina Lawan, Mantikas Muara, Setabu, Balang Situ, Tembaring, Tanjung Karang, Sungai Bajau, Tanjung Aru, Nyamuk River Pancang River, and Nunukan aquatic areas covering Balong River, Menteri River, Kampung Pukat, Pangkalan, Sedadap, Tanjung Harapan, Semeng Kado, and Fatima River.

In their fishing operation, most fishers had no capital for both operational and investments. All costs for these businesses were acquired from collectors in the concentration of each fisherman. These were middlemen who became their mainstay. The loan covered the cost of investment (procurement of ships, ship engines and fishing equipment) and operating costs each time they performed fishing trip. The total requirement of fund for each unit fishing of investment was approximately 10,000 ringgit or 30 million rupiah, whereas the operating costs ranged between 1,000 ringgit (IDR 3 million) and 4,000 ringgit (IDR 12 million).

The repayment patterns were performed at every time of fishing trip first, the catch yield would be cut according to operational costs owed by the fishers. Second, funding which had been cut was then distributed to the crew with different systems according to each of fishing equipment. For example, for units of hand line fishing capture, the income was divided into four parts two parts for the ship owner and the other two parts for a total crew of two people. Third, from the owner of the ship it would be cut by $20 \%$ more for installments of received investment costs. Installment of investment and operational costs fulfillment would last very long. Even when the fishing capture unit could not be used anymore, installments were not yet able to be repaid. If this condition occurred, fishers could obtain another loan from the owners of capital, and the remaining debt would be added to the new debt acquired. It is, indeed, this situation that caused the fishers would not be freed from the debt trap or bondage.

If the fishers did default, the capture unit would be taken by middlemen and payments (installment) that had been complete by the fishers were burned, which means that those payments were not counted anymore. The capture unit was then sold by middlemen or transferred to other fishers under the condition that debt payment of the previous fisherman was taken over by the new fisherman.

Collectors themselves were only an intermediary. They obtained the capital to be further distributed to the fishers of the local fishes investor (tauke) in Tawau. The Tawau Tauke actually could be classified into two groups namely, the tauke who owned a refinery and tauke who owned auction. Refinery tauke is the tauke who owned a refinery either a processing factory or cold storage treatment. There were about $8 \%$ refinery taukes in Tawau. The auction tauke, on the contrary, is tauke in the market that sells fish that fishers catched directly to the ultimate consumers. Most auction taukes (80\%) were Malays of Malaysia and the Malays of Bugis from Indonesia. Bugis people who became tauke were (1) The Bugis of Indonesian citizen, (2) Bugis people who have two nationalities. The latter case was likely to occur as those who have resided in Malaysia for 10 years would be entitled to become citizens of Malaysia, and (3) Bugis people of Indonesian nationality, but was married to Malaysian citizens either Bugis or not. 
Schematically, the distribution of this tauke was presented in Figure 1.

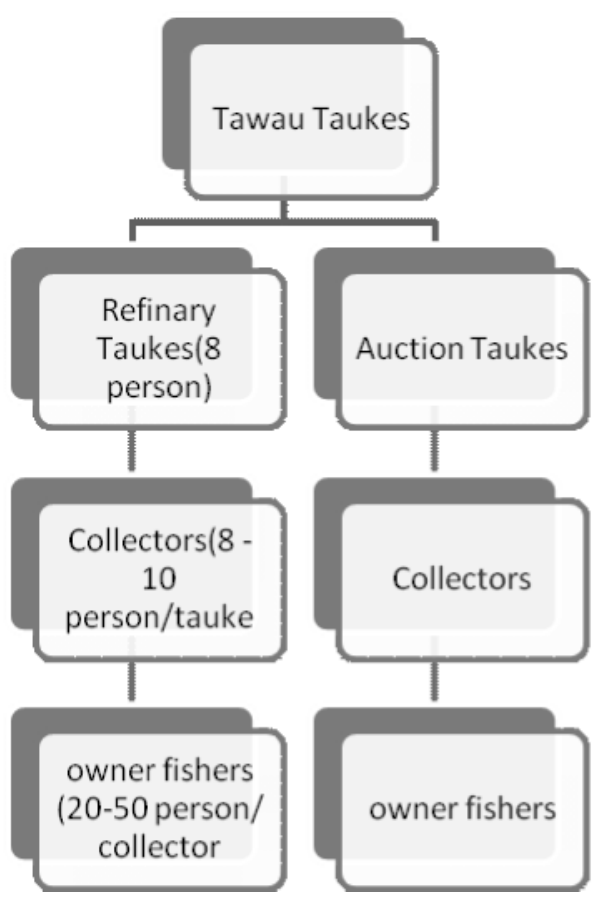

Figure 1. Division of Tawau Tauke.

The circulation of money for the fishing business handled by the tauke of Tawau was of big amount.
Based on calculations of data obtained, from information on the interview, the total funds disbursed only from refinery tauke could reach 120 billion rupiahs for investment and 48 billion for operational costs at each trip of fishing. If it is assumed that the crew at each fishing unit consists of 3 people, then the dependent fishers have about 1,200 fishers.

Moreover, the Tawau Tauke's role was so big that there was even a systemic attachment that made unable to be separated from the influence of this tauke. The existence of capital engagement also make it are unabled for fishers to sell their catch to other parties other than the collector merchants. Prices were determined by collector's traders and investors from Tawau.

Some of the prices of fish at the level of fishers, collectors and the market prices in Tawau were presented in Table 1.

In the context of the relationship, fishers were not parties who had a relatively large profit. Based on the price information presented in Table 1 and 2, the greatest price margins ranging from $50-125 \%$ were enjoyed by the tauke which compared to prices at the level of fishers. Meanwhile, when compared to the purchase prices at the level of middlemen, the profit margin ranged from $12-50 \%$.

Table 1. Fish price by species at the level of fishers Nunukan, collector, and market traders Tawau

\begin{tabular}{lccc}
\hline \multirow{2}{*}{ Fish } & \multicolumn{3}{c}{ Price level (Rp.) } \\
\cline { 2 - 4 } & $\begin{array}{c}\text { Purchasing prices } \\
\text { of the fishers }\end{array}$ & $\begin{array}{c}\text { Selling prices } \\
\text { to Tawau }\end{array}$ & $\begin{array}{c}\text { Market prices } \\
\text { in Tawau }\end{array}$ \\
\hline Spot shrimp (Udang bintik) & 10,500 & 12,600 & \\
Tiger shrimp (Udang tiger) & 78,000 & 90,000 & 120,000 \\
Jacks trevallies (Kuwe) & 12,000 & 18,000 & 27,000 \\
Blue tail mullet (Belanak) & 15,000 & 21,000 & 24,000 \\
Red snapper (Kakap merah) & 18,000 & 24,000 & 27,000 \\
Blue lined sea bass (Kerapu) & 18,000 & 24,000 & 30,000 \\
\hline
\end{tabular}

Sources: Interview Results 
Table 2. Calculated margin according to each species received by of fishers, collectors, and market traders in Tawau, 2009.

\begin{tabular}{lccc}
\hline \multicolumn{1}{c}{ Fish } & $\begin{array}{c}\text { Price margin at } \\
\text { the level of collector } \\
\text { compared to the level } \\
\text { of fishers (\%) }\end{array}$ & $\begin{array}{c}\text { Price margin at the level } \\
\text { of investor comparedto } \\
\text { the level of collector (\%) }\end{array}$ & $\begin{array}{c}\text { Price margin in Tawau } \\
\text { market compared to } \\
\text { the level of fishers (\%) }\end{array}$ \\
\hline $\begin{array}{l}\text { Spot shrimp } \\
\text { (Udang bintik) }\end{array}$ & 20.00 & 42.86 & 71.43 \\
$\begin{array}{l}\text { Tiger Shrimp } \\
\text { (Udang tiger) }\end{array}$ & 15.38 & 33.33 & 53.85 \\
$\begin{array}{l}\text { Jacks trevallies } \\
\text { (Kuwe) }\end{array}$ & 50.00 & 50.00 & 125.00 \\
$\begin{array}{l}\text { Blue tail mullet } \\
\text { (Belanak) }\end{array}$ & 40.00 & 14.29 & 60.00 \\
$\begin{array}{l}\text { Red snapper } \\
\text { (Kakap merah) }\end{array}$ & 33.33 & 12.50 & 50.00 \\
$\begin{array}{l}\text { Blue lined sea } \\
\text { bass } \\
\text { (Kerapu) }\end{array}$ & 33.33 & 25.00 & 66.67 \\
\hline
\end{tabular}

Sources: Interview Results

\section{Discussion}

It was discussed previously that one cause of relatively poor fishers was their limited access to capital for their fishing businesses. Moreover, for the fishers in the border areas, such as fishers in Nunukan Regency geographically, access to other areas in Indonesia were relatively limited. Accordingly, the relationship among the fishers, middlemen, and tauke from Tawau in the context of fishing effort was a necessity. On one hand, the fishers had no capital to conduct fishing efforts, and on the other hand, the tauke had an interest to rotate funds for profit gained. Most fishers of Nunukan Regency were dependent of loans of the tauke. It is reasonable if then this relationship was more dominant than fisherman relationship either with other investors from the domestic formal institutions or with formal lenders such as banks and non banks.

In addition, the conventional financial institutions have not currently been able to keep up with the supply of capital from the tauke of Tawau. Such powerlessness of formal financial institutions mainly due to asymmetrical information to not only identify potential loan recipients but also monitor their business. In the context of banking business that emphasizes the aspects of trust and confidence in the ability to pay, these two aspects are absolutely necessary. Formal financial institutions overcome the lack of information and inability in this monitoring by using the device collateral to prospective borrowers who just cannot be met by the fishers. In the institutional economic context namely, transaction, costs are the costs of arranging the contact ex ante, monitoring, and enforcing ex post (Matthews, 1986 in Hubbard, 1997).

Indeed, the relationship among fishers, middlemen, and the tauke were able to overcome this problem of asymmetric information. The perpetrators were not just implementing a contract system that borrows loan contracts, but applying some interconnection contracts (contract interlinkages) needed to minimize the transaction costs caused by this asymmetric information. In contrast to formal financial institutions, the tauke did not give limitation only to transactions and loans borrowed transactions, but also transactions where the tauke market, through intermediary traders, had the certainty to get the catch of fishers. Interrelation of loans and marketing was one of the fisheries market characteristics which showed that perfect competition did not occur in this product market (Charles, 2001). Some basic assumptions of perfect competition markets which were not met by the market of fishery products were (i) the number of sellers and buyers are relatively big. There was no one could control prices so there was no collusion between sellers and buyers (ii) there was a balance between supply prices and demand, and (iii) there adequate information available for all actors. As a result, the marketing system of fishing capture was contractually between the fishers and owners of capital.

In order to ensure funds would beused in accordance with its objectives, the capital owner put collectors to select as well as monitor the use of capital 
given. Tawau Tauke may not be directly familiar with the fishers who were given loans, but he trusted the collectors or middlemen to interact directly with the fishers. These middlemen were, in fact, the ones who come from the non fishers or fishers who knew other fishers, and they were rarely public figures. The process of monitoring conducted by these collectors were, in fact, relatively easy. The major principle used in the connection of fishers and middlemen or collectors were trust. Additional incentives were obtained from commissions paid by the Tawau Tauke as well from sales margin of fishers catch fish.

Beside that, there were social attachment among fishers, traders and their tauke or boss at Tawau where they all were Bugis of South Sulawesi. Bugis people who live in Tawau (can reach $70 \%$ of the population of Tawau) largely had ties to his hometown in Indonesia. As pointed out by Soekanto (2000) rural communities, including fishers of Nunukan has a close relationship and depth on the basis of kinship systems. The tightness of this relationship was then utilized in building relationships between actors in capture fisheries.

Thus, the problem of asymmetric information (which contains information on fishers identification of prospective borrowers and monitors the behavior of the fishing business) can then be solved by administrative requirements which cannot be applied to formal financial institutions namely, (i) the owners of capital do not require collateral for any transaction (ii) the provision of loans was not limited in number, and (iii) the ability to conduct transactions whenever needed, without complicated administrative rules.

Patterns of relationships, as mentioned above was an optimal pattern of relationships had ever held. However, such a pattern did not provide an opportunity for fishers to develop better. Fishers bear all risk of failure of the efforts of his fishing business while the biggest profit margin went to the owners of capital. The owners of capital, even though bear a risk of capital fund which was not returned due to failure of the fishing effort, they were still able to cover it from the sale of their catch in fishing trips before. As for fishers, on the other hand, they must bear all the losses and must continue to pay even if the installments were given in the long time limit.

Accordingly, efforts from the government in order to improve the welfare of fishers through various schemes of fishing arrangement should consider relationships patterns that have existed. Inaccuracy in determining goals and methods used will end up to the issue of wrong policies (misleading policy), which not only caused the unability of fishers to get out of poverty but also provided benefits to other parties outside of Indonesian fishers.

An example of such a case is the government policy on the use of hela trawl (PER.06/MEN/2008). Overall this policy will be responded positively by the owners of capital from Tawau as. It provides greater opportunities for them to greater amount of catch yield if fishers use this kind of equipment (hela trawl). However, with the pattern of relationships mentioned above, this policy will not significantly impact the income of fishers.

Nunukan fishers have only played their roles as operators of fish catch. The policy allowing the use of hela trawl needs to be viewed as one part of the process of both fishery development and fisherman empowerment in boundary regions. This policy, however, has to be followed other policies like by fisherman capital strengthening policy, regulations on yield catch marketing policy among Indonesia and neighboring countries, increasing the infrastructure and accessibility to domestic regions close to Nunukan, and providing stimulus for the development of fish processing industries in the border regions. In fact, Tawau is significantly potential to be the market of catch yield from Nunukan, nevertheless, there should be regulations that facilitate fishers of Nunukan to obtain more reasonable profits and to handle indirect fish resource exploitation performed by foreign parties.

\section{CONCLUSION}

1. The interactions of Nunukan fishers with foreign investors from Tawau were in the forms of capital provision for fish catch businesses, and market for the catch yield obtained.

2. The interaction built has not shown significant impact on the increase of income of fishers in Nunukan.

\section{ACKNOWLEDGEMENTS}

This paper is part of Doctor Dissertation at the Graduate School Bogor Agricultural University and title of Capture fisheries development model in border area (A Case Nunukan Regency East Kalimantan). This research supported by Doctoral Research Grant from Directorate Higher Education, Ministry of National Education 2009. 


\section{REFERENCES}

Charles, A. T. 2001. Sustainable Fishery System. Blackwell Science. United Kingdom. 370 pp.

Hubbard, M. 1997. The new institutional economic in agricultural development: Insights and challenges. Journal of Agricultural Economics. 48 (2): 239-249. Soekanto, S. 2000. Sosiologi Suatu Pengantar. P.T. Raja Grafindo Persada. Jakarta. 515 pp.
The Minister Regulation of Marine Affairs and Fisheries of the Republic of Indonesia Number PER.06/MEN/ 2008 Regarding Using Fishing Gear of Trawl in Northern Part East Kalimantan Waters.

The Presidential Regulation of the Republic of Indonesia Number 78 Year 2005 Regarding Management of Outer Small Island. 